$\xi=$

\title{
Phytoremediation of battery industry effluent through aquatic macrophytes
}

\author{
Mahrine Rashid ${ }^{1 *}$, Iftilkhar Ahmad ${ }^{1}$, Ashique Muhammad ${ }^{1}$, Mahmood Ul Hassan ${ }^{1}$ \\ ${ }^{1}$ Department of Plant and Environmental Protection Pakistan. PARC Institute of Advance Studies in Agriculture. National Agricul- \\ tural Research Centre, Islamabad The University of Agriculture, Peshawar, Pakistan \\ *Corresponding author E-mail: mahrine.rashid@gmail.com
}

\begin{abstract}
Research was conducted to quantify the level of copper $(\mathrm{Cu})$, chromium $(\mathrm{Cr})$, cadmium $(\mathrm{Cd})$ and lead $(\mathrm{Pb})$ contamination in battery industry effluent and to assess the remediation potential of three invasive aquatic macrophytes Eichhornia crassipes, Pistia stratiotes and Hydrocotyle umbellata by growing on industrial effluent collected from Lead acid Battery industry.

The effluent was heavily contaminated with $\mathrm{Pb}(10 \mathrm{mg} / \mathrm{l})$ and sulphuric acid $(\mathrm{pH} 2-2.1)$. Due to high $\mathrm{Pb}$ concentrations and low $\mathrm{pH}(2-2.2)$ the plants were unable to survive. Mortality rate of E. crassipes was $96 \%$ while P. stratiotes and H. umbellata were $100 \%$ rotten. The experiment was repeated after adjusting the effluent $\mathrm{pH}$ to 7-7.5 to increase the plant life.

Plant parts and wastewater samples were analyzed after every 3 days interval uptil 21 st day. The amount of $\mathrm{Cr}, \mathrm{Cd}$ and $\mathrm{Cu}$ in the effluent was $0.076 \mathrm{mg} / \mathrm{L}, 0.036 \mathrm{mg} / \mathrm{L}$ and $0.097 \mathrm{mg} / \mathrm{L}$, which was in permissible limits of NEQs $(1.0 \mathrm{mg} / \mathrm{l}, 0.1 \mathrm{mg} / \mathrm{l}$ and $1.0 \mathrm{mg} / \mathrm{l}) \mathrm{respectively}$. $\mathrm{Pb}$ was found 10 times higher i.e. $10 \mathrm{mg} / \mathrm{l}$ than the permissible limit $0.5 \mathrm{mg} / \mathrm{l}$. E. crassipes removed $\mathrm{Pb}>\mathrm{Cr}>\mathrm{Cu}>\mathrm{Cd}$ while $P$. stratiotes and H. umbellata reduced $\mathrm{Cd}, \mathrm{Cr}, \mathrm{Cu}$ more than $\mathrm{Pb}$ from the effluent. E. crassipes was most efficient $\mathrm{Pb}$ removing plant in 21 days of experiment.
\end{abstract}

Keywords: Battery Industry; Effluent; Invasive Aquatic Macrophytes; Pb; Phytoremediation; Water Hyacinth.

\section{Introduction}

Heavy metals are among most hazardous environmental pollutants. Besides natural activities, almost all human activities also contribute to production of metals as a side effect. Migration of these pollutants to contaminated sites such as effluents, sewage, dust or leaching into the soil is a common examples of events contributing to infection (Bieby Voijant Tangahu et al., 2011). Contamination of soil, surface and groundwater is key environmental problem causing accumulation of heavy metals and many other pollutants resulting in the deterioration of biological ecosystems.

Heavy metals such as lead $(\mathrm{Pb})$, chromium $(\mathrm{Cr})$, zinc $(\mathrm{Zn})$, cadmium $(\mathrm{Cd})$, copper $\mathrm{Cu})$, and nickel $(\mathrm{Ni})$ are contaminating forms, which are produced in large quantities by improper disposal of batteries, household, industrial, agricultural and mining waste and eventually causing severe environmental impact. These components produce bioaccumulation effects, categorizing them as precarious elements that are necessary to be removed from ecosystem (Cleide Barbieri de Souza and Gabriel Rodrigues Silva, 2019). Toxic heavy metals which include $\mathrm{Pb}$, Co, Cd may be differentiated from other pollutants, on the grounds that they can't be biodegraded but may be accrued in living organisms, therefore causing various diseases and issues even in extraordinarily decrease concentrations (Bieby Voijant Tangahu et al., 2011). Main focus of the current study is phytoremediation of Battery industry effluent. Lead acid batteries have become a widespread power source for commercial, household and industrial applications but the use of non-toxic and non-hazardous substitute materials has not rapidly developed (Buchmann, 2011). According to a 2005 estimate, the worldwide battery industry generates US \$ 48 billion in sales each year (MIT, 2009) with 6\% once a year growth. In Pakistan, there are 39 battery manufacturing industries dealing with different types of batteries (http://www.pakbd.com/company).

Battery wastewater is distinguished by heavy metals chiefly, like lead $(\mathrm{Pb})$, cadmium $(\mathrm{Cd})$, chromium $(\mathrm{Cr}), \mathrm{Copper}(\mathrm{Cu})$, mercury $(\mathrm{Hg})$, arsenic (As) etc and, chlorine and sulphates, biological oxygen demand (BOD), chemical oxygen demand (COD) and total dissolve solids (TDS). Level of the pollutants in lead acid battery wastewater depends on process of battery manufacturing (Ramus and Hawkins, 1992). Batteries contain acerbic effects that can cause burns and are hazardous to eyes and skin (MIT, 2009).

Lead is an ancient metal recognized and used by humans; nevertheless it is severely lethal to humans and aquatic life. The high levels of lead $(\mathrm{Pb})$ may result in toxic effects in humans which in turn cause problems in the synthesis of blood $(\mathrm{Hb})$, defect kidneys, reproductive system, gastrointestinal tract (GIT), joints, and severe damage to nervous system (Govind and Madhuri, 2014). Workers exposed to lead were found to be impaired respiratory function and with elevated blood lead and zinc protoporphyrin concentration (Jurdziak et al., 2015). A study conducted on Uruguayan in first grade children showed oxidative stress by low level lead exposure, signifying its potentially adverse effects (Roy et al., 2015). Excess Pb toxicity may cause number of morphological and physiological impacts in plants e.g. stunted growth, chlorosis blackening of root system, it inhabits photosynthesis, imbalance nutrition and water balance etc in plant (Pallavi and Dubey, 2005). Chromium (Cr) is toxic and produces anaemia in human and change in hematological parameters in the L. rohita fish (Praveen et al., 2013). The cadmium (Cd) may cause increased blood pressure, kidney dysfunction, and respiratory problems. Similarly, 
exposure to nickel (Ni) can cause decrease in body weight, heart and liver damage, and skin irritation. Mutagenicity, carcinogenicity, teratogenicity, immunosuppression, poor body condition and impaired reproduction are toxic effects of heavy metals (Govind and Madhuri, 2014).

Bioaccumulations of large quantities of heavy metals and its toxic effects on biota has led to various research studies and methods for management and treatment of heavy metal polluted water (Gupta, 2013).

Expensive conventional methods and environmental hazards have enforced scientists to explore cost effective ways to remove heavy metals from effluent. For similar reasons, biologists have focused on accumulation of heavy metals by aquatic macrophytes and reported bioremediation through plants is effective way of treating industrial effluent. (Licina et al., 2007). Several aquatic macrophytes such as Eichhornia crassipes, Lemna sp., Azolla sp., Spirodella sp. and Pistia sp. Are frequently and effectively have been used for removing heavy metals from different industrial effluent (Gupta etl. 2012; Saha et al 2015)

Plants utilized for phytoremediation must possess capability of rapid growth, high biomass, hairy and deep-root system, and high bioaccumulation coefficient. (Pooja and Kaushal , 2018). The free floating/floating-leaved aquatic plants like water lettuce (Pistia stratiotes), common salvinia (Salvinia minima), water hyacinth (Eichhornia crassipes), duckweed (Lemna spp. and Spirodela polyrrhiza), pennywort (Hydrocotyle umbellata) are suitable candidates for heavy metal removal (Cleide Barbieri de Souza and Gabriel Rodrigues Silva. 2018, John et al., 2008; Maine et al., 2004; Mishra et al., 2008; Sanchez-Galvan et al., 2008).

These aquatic plants have ability to absorb high levels of contaminants concentrated either in their roots, shoots and/or leaves (Raksin et al., 1994; Cunningham and Ow 1996; Baker et al., 1994). Baker and Brooks (1998) studies revealed that metal accumulated in plants contain more than or up to $0.1 \%$ i.e. $>1000 \mathrm{mg} / \mathrm{g}$ of copper, cadmium, chromium, lead, nickel. For cadmium and other rare metals, it is > $0.01 \%$ by dry weight. Therefore, macrophytes have been frequently experienced for heavy metal removal (Mishra and Tripathi, 2008). Several aquatic species like water pennywort (Hydrocotyle umbellate L.), duckweed (Lemna minor L.) (Mo et al., 1989) and water hyacinth (Eichhornia crassipes Mart. Solms have shown ability to remove heavy metals from water, (Zhu et al., 1999).

In this study, the research objective are to quantify levels of heavy metals i.e. Lead $(\mathrm{Pb})$, Copper $(\mathrm{Cu}), \mathrm{Chromium}(\mathrm{Cr}), \mathrm{Cadmium}(\mathrm{Cd})$ in the wastewater of battery industry, evaluation of remediating efficacy of three aquatic plants i.e. Pistia stratiotes, Hydrocotyle umbellata and Eichhornia crassipes and to demonstrate their capability of removing heavy metals $(\mathrm{Pb}, \mathrm{Cu}, \mathrm{Cr}, \mathrm{Cd})$ from the wastewater and screen out best candidate specie for management of battery industry effluent. These metals were selected for their toxic properties, their capability to contaminate environment and their high indices in effluents. The selected plants were reported most abundant, fast growing and prominent in research studies.

\section{Materials and methods}

\subsection{Study area}

Hattar Industrial Estate is an area of 1,063 acres (containing 215 houses operational and 378 closed, 162 under construction and 98 sick industrial units); this industrial estate encloses chemical, vegetable oil manufacturing, steel, paper, cement, marble, pharmaceutical, textile, Lead acid battery, poultry feed and beverages industries. According Environmental Protection Agency (EPA) report these factories are key source of pollution in area (Sial et al., 2006). The area is surrounded by natural surface drains and the effluents of all the factories are disposed in these aquifers and ultimately fall into the Haro River.

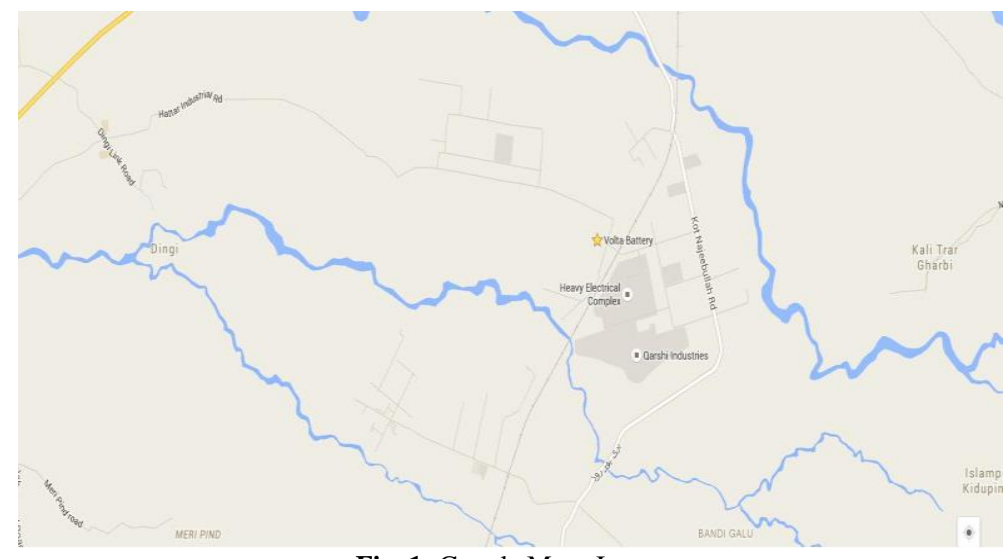

Fig. 1: Google Maps Image

\subsection{Material and method}

\subsubsection{Water samples collection and analysis}

Untreated industrial effluents of Lead acid Battery industry, Taxila were collected from the study site and stored in polythene bottles for initial characterization and phytoremediation experiments. The samples were subjected to nitric acid digestion using the microwave-assisted technique, setting pressure at 30 bars and power at 700 Watts (Lokhande et al., 2011). Standard methods and procedures (APHA $2001)$ were used to analyze physiochemical properties, $\mathrm{pH}$ and temperature. Copper $(\mathrm{Cu}), \mathrm{Chromium}(\mathrm{Cr}), \mathrm{Cadmium}(\mathrm{Cd})$ and $\mathrm{Lead}(\mathrm{Pb})$ was analyzed by using Atomic Absorption Spectrometry Perklin Elmer- AAnalyst 700 at Water and Soil Analysis Lab according to methods (Clesceri et al., 1998).

i). Plant analysis:

Plants (Water Lettuce, Pennywort and water hyacinth) were acclimatized in plastic tubs with fresh water in 45 days. After 45 days twenty five plants of each species (Water Lettuce, Pennywort and water hyacinth) were set in effluent (at least 20 lit/ tub) and allowed to stay in effluent for 21 days (Ganjo and Khwakaram, 2010). Plant samples from each experimental tub were harvested and analyzed according to standard methods of APHA (1998) for heavy metal Copper (Cu), Chromium (Cr), Cadmium (Cd) and Lead (Pb) at Land Resource Research Institute (LRRI) PARC, Islamabad by Atomic Absorption Spectrometry (AAS). 
Plant species were for heavy metals For heavy metal analysis the plant samples were washed with distilled water, air dried and placed in oven at $70-80^{\circ} \mathrm{C}$ for 48 hours (Rathor et al, 2014). The powder form of different parts of plants was digested using double acids mixture (nitric and perchloric acid) and filtered through Whatman 42 filter paper. After nitric and perchloric acid digestion, the solution was transferred to $50 \mathrm{ml}$ volumetric balloon and reading under taken by Atomic Absorption Spectrometer for heavy metals. Analysis of heavy metals was done after every 3 days for at least 21days as performed by Upadhyay et al., 2007.

The $\mathrm{pH}$ of effluent was 2.1 which was adjusted to $7-7.5$ for plant survival. The heavy metal uptake from contaminated battery effluent by Water Lettuce (Pistia stratiotes), Pennywort (Hydrocotyle umbellata.), and water hyacinth (Eichhornia crassipes) was recorded. Experiment was performed in triplicate under natural conditions for 21 days Hydraulic Retention Time (A. R. Upadhyay et al., 2007). The effluent and plants were sampled periodically after every 3 days for a period of 21 days and analyzed for physicochemical parameters (Tangahu et al., 2011).

ii). Translocation Factor:

Translocation factor (movement ability of plants to accumulate heavy metal in shoots and roots) was calculated by equation $\mathrm{TF}=\left(\frac{\mathrm{Cs}}{\mathrm{Cr}}\right) \mathrm{i}$, where i denotes the heavy metal. Cr represents the amount of trace element accumulated in the roots $(\mathrm{mg} / \mathrm{kg})$ and Cs represents the amount of trace element accumulated in the shoots (mg/ kg) (Sivalingam et al., 2016).

iii). Bioconcentration Factor :

Bioconcentration (amount of heavy metal in plant tissue and in surrounding environment) was calculated by equation $\mathrm{BCF}=\left(\frac{\mathrm{P}}{\mathrm{E}}\right) \mathrm{i}, \mathrm{Where}$ $\mathrm{i}$ denote the heavy metal, $\mathrm{P}$ represents trace element concentration in plant tissues ( $\mathrm{mg} / \mathrm{kg}$ dry wt.); E represents the trace element concentration in the water $(\mathrm{mg} / \mathrm{L})$ or in the sediment $(\mathrm{mg} / \mathrm{kg})$ (Sivalingam et al., 2016).

\subsubsection{Statistical Analysis}

Three aquatic plant species with three replicates were arranged in completely randomized design (CRD). The data was statistically analyzed using two factor (Plant species and time) factorial experiment under CRD. Analysis of variance (ANOVA) of the measured parameters was performed using Statistix 8.1 or Minitab 15 software. Results were represented in graphs and tables with the help of Microsoft Excel 2010 .

\section{Results}

Analysis of effluents for the baseline data showed $\mathrm{Pb}(\mathrm{lead})$ to be ten times higher than permissible limits $(0.5 \mathrm{mg} / \mathrm{l})$ either for effluent disposal to environment or for agricultural usage. Table 1 showed the $\mathrm{pH}$ value range from $2.1-2.3$ which is under the permissible limits (highly acidic) described by National Environmental Quality Standards (NEQS) 6-10 at constant temperature value $30-35^{\circ} \mathrm{C}$. Cr, Cd and $\mathrm{Cu}$ in effluent was $0.076 \mathrm{mg} / \mathrm{L}, 0.036 \mathrm{mg} / \mathrm{L}$ and $0.097 \mathrm{mg} / \mathrm{L}$ respectively which is in the permissible limits of NEQs $(1.0 \mathrm{mg} / 1,0.1 \mathrm{mg} / \mathrm{l}$ and $1.0 \mathrm{mg} / \mathrm{l})$ respectively. Waste water characteristics are listed in Table 1.

Experiment was started by adjusting $\mathrm{pH}$ to $7.0-7.5$ using $\mathrm{NaOH}$ (1 liter effluent $+7 \mathrm{ml}$ of $1 \mathrm{M} \mathrm{NaOH}) .25 \mathrm{plants}$ of E. crassipes, P. stratiotes and $H$. umbellata were placed in effluent. Plants and water samples were taken for the analysis of heavy metal after every third day of the experiment $(0,3,6,9,13,15,18$ and 21$)$. Positive control was set with tap water and experimental plants.

Table 1: Physico-chemical analysis of the effluent of battery industry

\begin{tabular}{|c|c|c|c|}
\hline Parameter & $\begin{array}{c}\text { Effluent } \\
\text { range }\end{array}$ & NEQs for industrial effluent $*$ & $\begin{array}{c}\text { Agriculture standard values } \\
(\text { WHO) })^{* *}\end{array}$ \\
\hline Temperature & $30-35^{0} \mathrm{C}$ & $40^{0} \mathrm{C}$ & $40^{0} \mathrm{C}$ \\
\hline $\mathbf{p H}$ & 2.1 & $6-10$ & $6.5-8.5$ \\
\hline $\mathbf{T D S}$ & 9930 & $3500 \mathrm{mg} / \mathrm{l}$ & $450-2000 \mathrm{mg} / \mathrm{l}$ \\
\hline $\mathbf{P b}$ & $10 \mathrm{mg} / \mathrm{L}$ & $0.5 \mathrm{mg} / \mathrm{l}$ & $0.5 \mathrm{mg} / \mathrm{l}$ \\
\hline $\mathbf{C d}$ & $0.036 \mathrm{mg} / \mathrm{L}$ & $0.1 \mathrm{mg} / \mathrm{l}$. & $0.1 \mathrm{mg} / \mathrm{l} / \mathrm{l}$ \\
\hline $\mathbf{C r}$ & $0.076 \mathrm{mg} / \mathrm{L}$ & $1.0 \mathrm{mg} / \mathrm{l}$. & $0.01 \mathrm{mg} / \mathrm{l}$ \\
\hline $\mathbf{C u}$ & $0.097 \mathrm{mg} / \mathrm{L}$ & $1.0 \mathrm{mg} / \mathrm{l}$. & \\
\hline
\end{tabular}

* National environmental quality standards (NEQs) for municipal and liquid industrial effluents (mg/l; the Gazette of Pakistan, Extra, August 10, 2000.

**World Health organization, Guidelines for drinking water quality. 1993.

\subsection{Average concentration of heavy metals in plants}

The average amount of lead in E. crassipes and P. stratiotes $(1999 \mathrm{mg} / \mathrm{kg}, 1276 \mathrm{mg} / \mathrm{kg})$ respectively were higher than pennywort (928 $\mathrm{mg} / \mathrm{kg})$. The average amount of Cd was higher in E. crassipes $(157.5 \mathrm{mg} / \mathrm{kg})$ than H. umbellata and P. stratiotes $(96 \mathrm{mg} / \mathrm{kg}, 56.4 \mathrm{mg} / \mathrm{kg})$. Cr was found higher in $P$. stratiotes $(210 \mathrm{mg} / \mathrm{kg})$ than E. crassipes and $H$. umbellata $(182.6 \mathrm{mg} / \mathrm{kg}, 149 \mathrm{mg} / \mathrm{kg})$. Cu was found higher in H. umbellata (52 mg/kg) than P. stratiotes and E. crassipes $(40.3 \mathrm{mg} / \mathrm{kg}, 30.2 \mathrm{mg} / \mathrm{kg}$ ) (Fig: 1; A, B, C, D) 
Figure 1: Concentration of heavy metals in plants

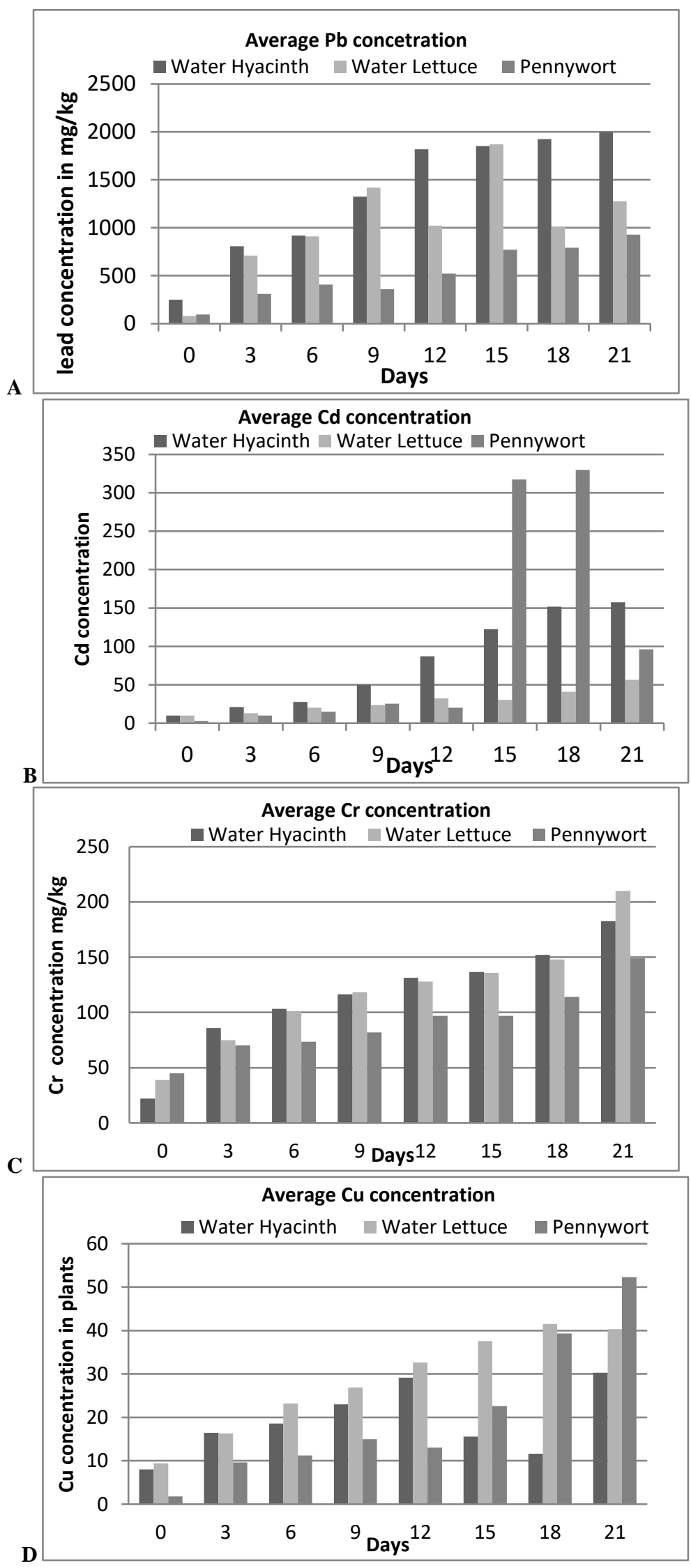




\subsection{Translocation Factor (TA)}

Figure 2 (A, B, C, D) explains translocation ability of plants to accumulate heavy metal in shoots and roots.

$\mathrm{Pb}$ was highly accumulated in roots of E. crassipes $(1220 \mathrm{mg} / \mathrm{kg})$ than $P$. stratiotes and H. umbellata roots $(813 \mathrm{mg} / \mathrm{kg} \mathrm{and} 255 \mathrm{mg} / \mathrm{kg}$ respectively), while shoots of $H$. umbellata were highest accumulators of $\mathrm{Pb}(268 \mathrm{mg} / \mathrm{kg})$ than shoots of E. crassipes and P. stratiotes (142 $\mathrm{mg} / \mathrm{kg}$ and $224 \mathrm{mg} / \mathrm{kg}$ respectively). Cd was highly accumulated in roots of $H$. umbellata $(89 \mathrm{mg} / \mathrm{kg})$ than roots of $E$. crassipes and $P$. stratiotes $(51 \mathrm{mg} / \mathrm{kg}, 23 \mathrm{mg} / \mathrm{kg})$ while $28 \mathrm{mg} / \mathrm{kg}$ was accumulated in E. crassipes shoots and $6 \mathrm{mg} / \mathrm{kg}$ and $13 \mathrm{mg} / \mathrm{kg}$ in shoots of $P$. stratiotes and $H$. umbellata. Cr was more accumulated in roots of E. crassipes $(80 \mathrm{mg} / \mathrm{kg})$ than shoots $(36 \mathrm{mg} / \mathrm{kg})$ while $65 \mathrm{mg} / \mathrm{kg} \mathrm{and} 47 \mathrm{mg} / \mathrm{kg}$ were recorded in roots of $P$. stratiotes and $H$. umbellata and in shoots $55 \mathrm{mg} / \mathrm{kg}$ and $44 \mathrm{mg} / \mathrm{kg}$ respectively. The accumulation and translocation of $\mathrm{Cu}$ was found to be relatively higher in roots $(13 \mathrm{mg} / \mathrm{kg}, 15 \mathrm{mg} / \mathrm{kg}, 12 \mathrm{mg} / \mathrm{kg})$ than shoots of E. crassipes, $P$. stratiotes and H. umbellata (6 mg/kg, $13 \mathrm{mg} / \mathrm{kg}, 8 \mathrm{mg} / \mathrm{kg}$ respectively).

Figure 2: Translocation of heavy metals in Shoot vs. Root
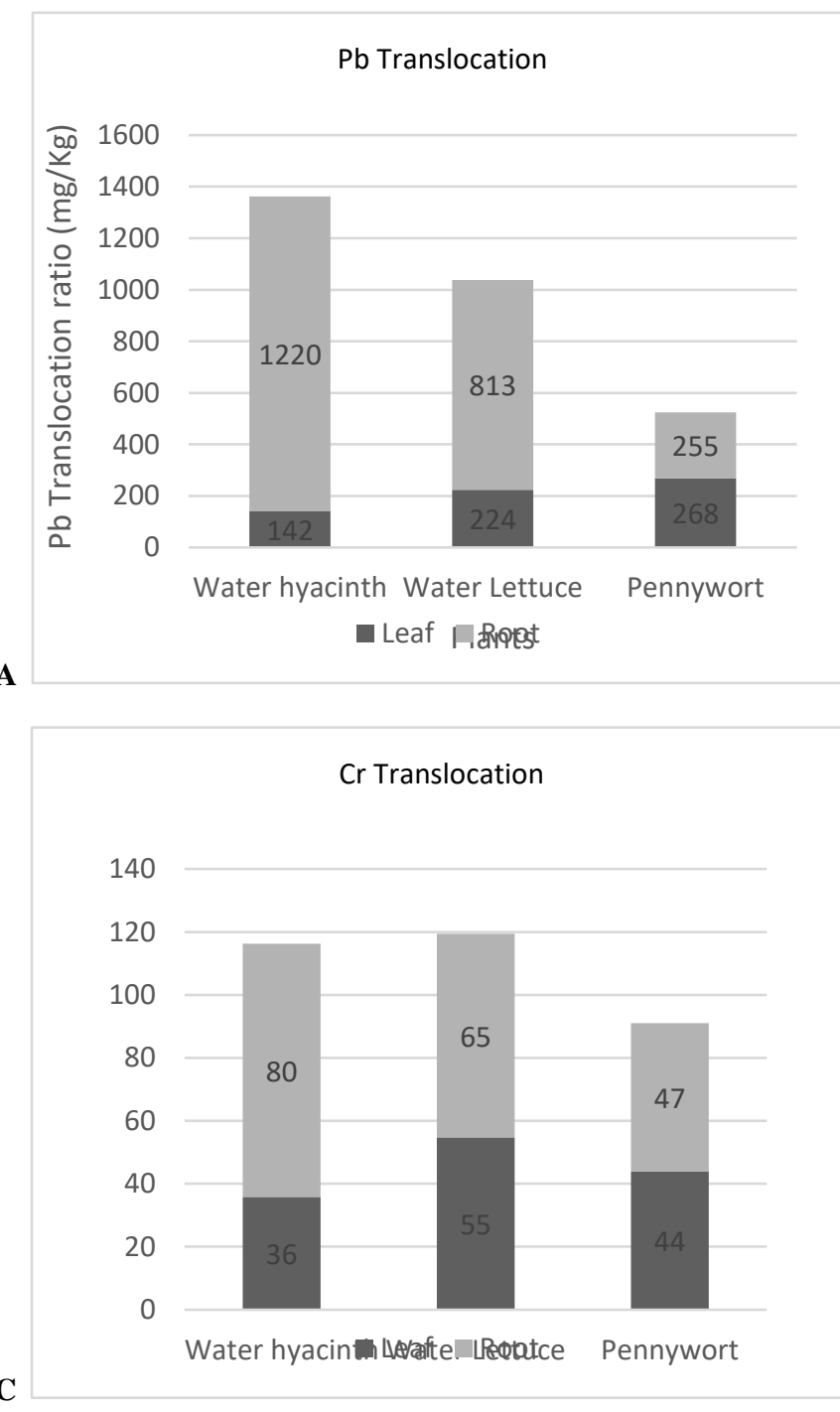
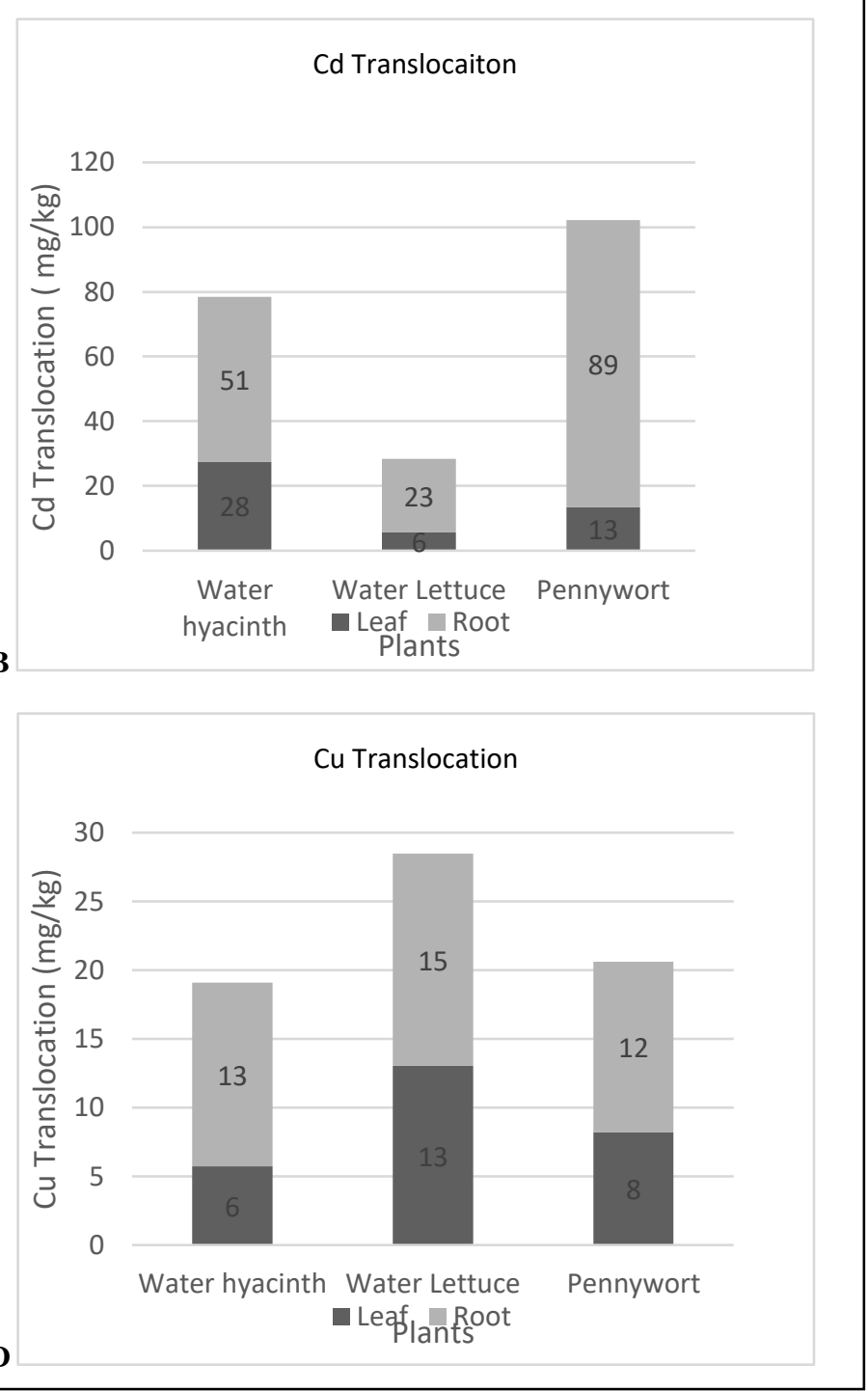


\subsection{Heavy metal removal efficacy}

All three plants were found to be hyperaccumulator of $\mathrm{Pb}, \mathrm{Cd}, \mathrm{Cr}$ and $\mathrm{Cu}$. E. crassipes accumulated $100 \% \mathrm{~Pb}$ and $\mathrm{Cr}, 86 \% \mathrm{Cd}, 93 \% \mathrm{Cu}$, P. stratiotes accumulated $98 \% \mathrm{~Pb}$, and $100 \% \mathrm{Cd}, \mathrm{Cr}$ and $\mathrm{Cu}$ while $\mathrm{H}$. umbellata $85 \%$ removed $\mathrm{Pb}$ and $100 \% \mathrm{Cd}, \mathrm{Cr}$ and $\mathrm{Cu}(\mathrm{Fig} 3 \mathrm{~A}, \mathrm{~B}$ ). Removal of $\mathrm{Pb}$ from effluent was highly recorded in E crassipes with constant and gradual uptake from day 1 to day 21 (250 mg/l, 3911 $\mathrm{mg} / \mathrm{l})$ as compared to $P$. stratiotes $(80 \mathrm{mg} / \mathrm{l}, 1276 \mathrm{mg} / \mathrm{l})$ and $\mathrm{H}$. umbellata $(97 \mathrm{mg} / \mathrm{l}, 928 \mathrm{mg} / \mathrm{l})$ respectively (Fig $4 \mathrm{~A}, \mathrm{~B}, \mathrm{C}) \mathrm{in}$ which fluctuation from day 9 to day 21 in absorption was observed.

Figure 3: Percentage removal efficacy of plants
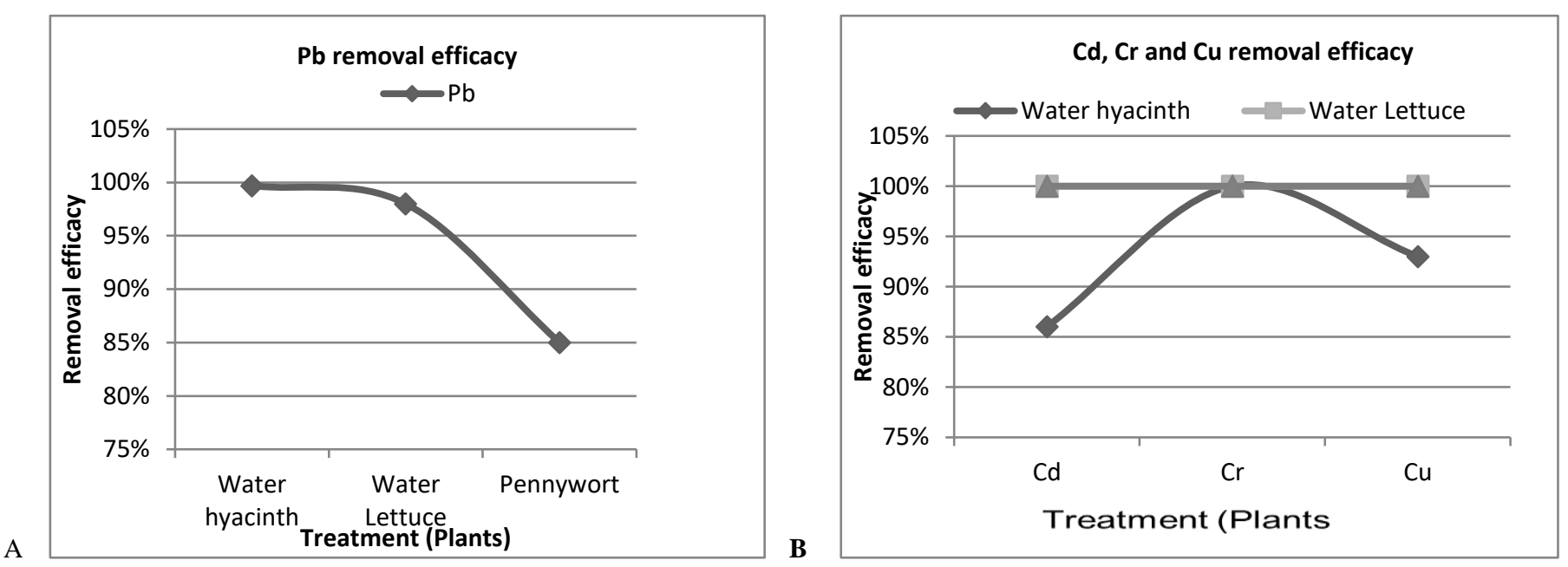

E. crassipes absorbed $100 \% \mathrm{~Pb}, 86 \% \mathrm{Cd}, 100 \% \mathrm{Cr}$ and $93 \% \mathrm{Cu}, P$. stratiotes reduced $98 \% \mathrm{~Pb}, 100 \% \mathrm{Cd}, 100 \% \mathrm{Cr}$ and $100 \% \mathrm{Cu}$ and $H$. umbellata reduced $85 \% \mathrm{~Pb}, 100 \% \mathrm{Cd}, 100 \% \mathrm{Cr}$ and $100 \% \mathrm{Cu}$ from the effluent. E. crassipes removed $\mathrm{Pb}>\mathrm{Cr}>\mathrm{Cu}>\mathrm{Cd}$ while $P$. stratiotes and $\mathrm{H}$. umbellata reduced $\mathrm{Cd}, \mathrm{Cr}, \mathrm{Cu}$ more than $\mathrm{Pb}$ from the effluent (Table 2). E. crassipes was most efficient $\mathrm{Pb}$ removing plant in 21 days of experiment.

Table 2: Removal of Heavy metal from effluent

\begin{tabular}{|c|c|c|c|c|c|c|}
\hline $\begin{array}{l}\text { Heavy } \\
\text { metals } \\
\text { (HMs) }\end{array}$ & $\begin{array}{c}\text { HMs in efflu- } \\
\text { ent } \\
1^{\text {st }} \text { day (mg/l) }\end{array}$ & Plants in effluent & $\begin{array}{c}\text { HMs in efflu- } \\
\text { ent } \\
21^{\text {st }} \text { day } \\
\text { (mg/l) }\end{array}$ & $\begin{array}{l}\text { \% age decrease of } \\
\text { HMs from effluent }\end{array}$ & $\begin{array}{l}\text { NEQs for in- } \\
\text { dustrial efflu- } \\
\text { ent } *\end{array}$ & $\begin{array}{c}\text { Agriculture } \\
\text { standard values } \\
(\mathrm{WHO})^{* *}\end{array}$ \\
\hline \multirow[t]{3}{*}{$\mathrm{Pb}$} & \multirow[t]{3}{*}{$10(\mathrm{mg} / \mathrm{l})$} & E. crassipes & 0.027 & $100 \%$ & \multirow[t]{3}{*}{$0.5 \mathrm{mg} / \mathrm{l}$} & \multirow[t]{3}{*}{$>0.5 \mathrm{mg} / \mathrm{l}$} \\
\hline & & P. stratiotes & 0.2 & $98 \%$ & & \\
\hline & & H. umbellata & 1.5 & $85 \%$ & & \\
\hline \multirow[t]{3}{*}{ Cd } & \multirow[t]{3}{*}{$0.036(\mathrm{mg} / \mathrm{l})$} & E. crassipes & 0.005 & $86 \%$ & \multirow[t]{3}{*}{0.1 mg/l. } & \multirow[t]{3}{*}{$0.01 \mathrm{mg} / \mathrm{l}$} \\
\hline & & P. stratiotes & 0.000 & $100 \%$ & & \\
\hline & & H. umbellata & 0.000 & $100 \%$ & & \\
\hline \multirow[t]{3}{*}{$\mathrm{Cr}$} & \multirow[t]{3}{*}{$0.076(\mathrm{mg} / \mathrm{l})$} & E. crassipes & 0.000 & $100 \%$ & \multirow[t]{3}{*}{1.0 mg/l. } & \multirow[t]{3}{*}{$0.1 \mathrm{mg} / \mathrm{l}$} \\
\hline & & P. stratiotes & 0.000 & $100 \%$ & & \\
\hline & & H. umbellata & 0.000 & $100 \%$ & & \\
\hline \multirow[t]{3}{*}{$\mathrm{Cu}$} & \multirow[t]{3}{*}{0.097 (mg/l) } & E. crassipes & 0.007 & $93 \%$ & \multirow[t]{3}{*}{1.0 mg/l. } & \multirow[t]{3}{*}{$0.01 \mathrm{mg} / \mathrm{l}$} \\
\hline & & P. stratiotes & 0.000 & $100 \%$ & & \\
\hline & & H. umbellata & 0.000 & $100 \%$ & & \\
\hline
\end{tabular}

* National environmental quality standards (NEQs) for municipal and liquid industrial effluents (mg/l; the Gazette of Pakistan, Extra, August 10, 2000.

**World Health organization, Guidelines for drinking water quality. 1993 
Figure 4: Pb removal from effluent and uptake by plants

A. Water hyacinth

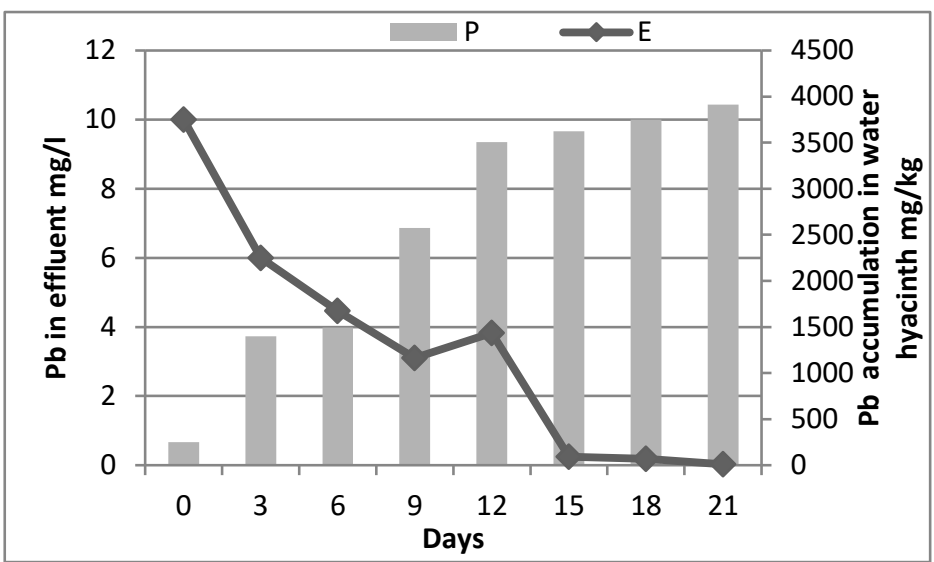

B. Water lettuce

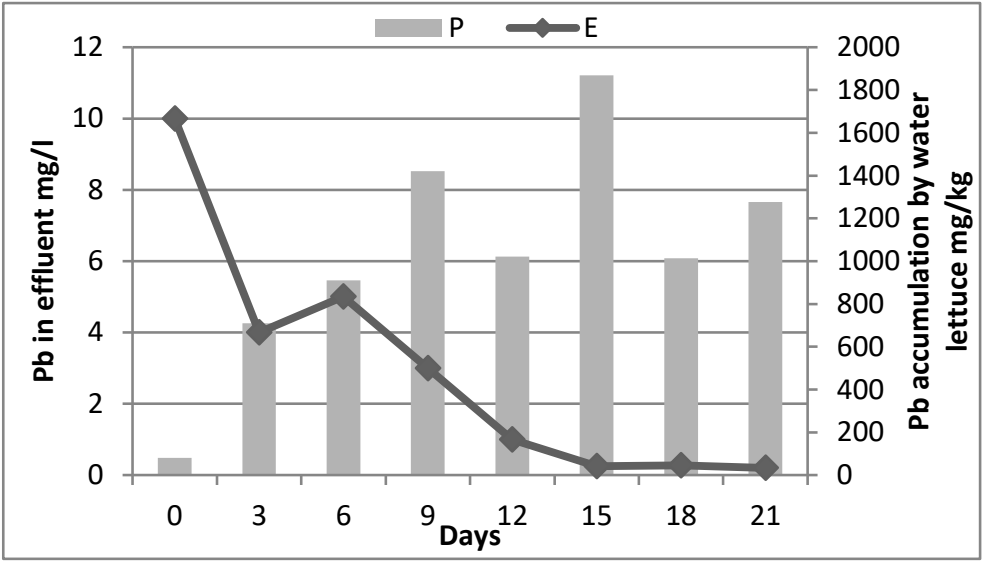

C. Pennywort

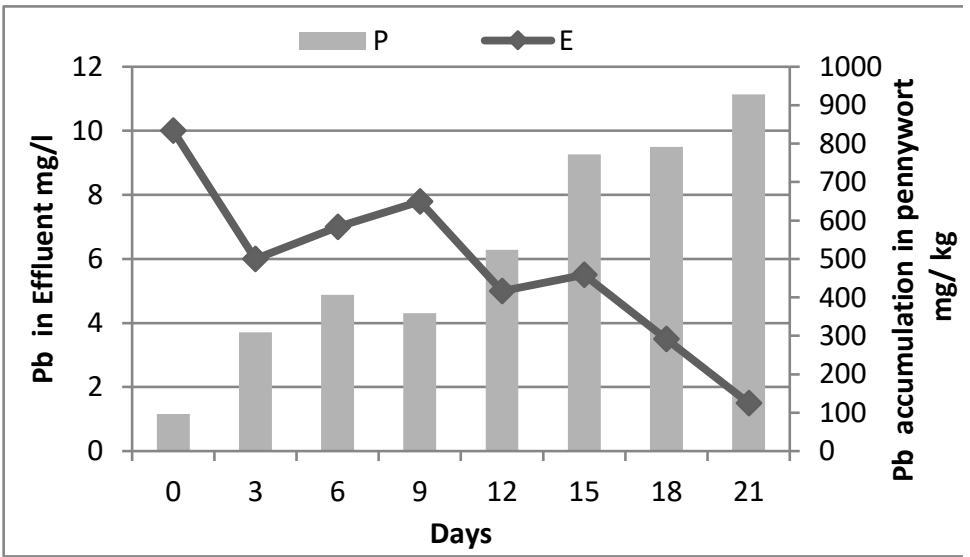


Analysis of Variance (ANOVA) of the measured parameters was performed using software Statistix 8.1 and variable means were compared using Least Significant Difference (LSD). All the means were significantly different from one another. The mean maximum and minimum contents of heavy metals in aquatic plants are listed in table 3. According to data presented (Tab. 3), higher mean content of $\mathrm{Pb}$ was found in E. crassipes (1412.9) at 5\% and least was absorbed by $H$. umbellata. Higher mean contents of Cd were found in H. umbellata (103.49) and least in $P$. stratiotes (28.35). Similarly, $\mathrm{Cr}$ and $\mathrm{Cu}$ was significantly absorbed by $P$. stratiotes $(119.41,28.47)$ and least absorbed by $H$. umbellata and E. crassipes $(91.00,19.068)$ respectively.

Table 3: Means showing heavy metals $(\mathrm{Pb}, \mathrm{Cd}, \mathrm{Cr}$ and $\mathrm{Cu})$ accumulation values.

\begin{tabular}{|l|c|c|c|c|}
\hline Treatment & Pb & Cd & Cr & Cu \\
\hline E. crassipes & $1412.9 \mathbf{A}$ & $75.97 \mathbf{B}$ & $116.32 \mathbf{B}$ & $19.068 \mathbf{C}$ \\
\hline P. stratiotes & $958.9 \mathbf{B}$ & $28.35 \mathbf{C}$ & $119.41 \mathbf{A}$ & $28.47 \mathbf{A}$ \\
\hline H. umbellata & $517.4 \mathbf{C}$ & $103.49 \mathbf{A}$ & $91.00 \mathbf{C}$ & $20.603 \mathbf{B}$ \\
\hline LSD $(5 \%)$ & 3.4298 & 1.0470 & 1.6813 & 0.9616 \\
\hline
\end{tabular}

At the end of experiment, physical condition was recorded. Necrosis, stunted growth and lack of chlorophyll were observed in plant leaves of all plants. Symptoms of water deficiency in plants were also recorded. No new plantlets were produced neither flowering occurred while reverse conditions like new plantlets, flowering and fresh green leaves were observed in the control condition (tap water). P. stratiotes showed lack of new plantlet production, necrosis and rolling of leaf tips. H. umbellata exhibited chlorosis, stunted growth and no production of new plantlets (Plate 4). Water deficiency, no new plantlets and flowering was observed in E.crassipes leaves at the end of experiment. In the control condition all plants produced new plantlets, flowering and leaves were found fresh green indicating maximum chlorophyll contents in plants.

\section{Discussion}

The research carried out to decontaminate the industrial effluent by using aquatic plants $E$. crassipes, $P$. stratiotes and $H$. umbellata, making it under the permissible limits for disposal. The objective of study was to analyze the chemical composition of battery industry effluent and reduce its hazardous impacts (Heavy metals). Lead $(\mathrm{Pb})$ and sulfuric acid are main component of Battery manufacturing industry. The chemical composition of effluent was dominated by highly acidic $\mathrm{pH}(2.1)$ and $\mathrm{Pb}(10 \mathrm{mg} / \mathrm{l})$. Other metals $(\mathrm{Cd}, \mathrm{Cr}, \mathrm{Cu})$ were under the permissible limits $(0.036 \mathrm{mg} / \mathrm{l}, 0.076 \mathrm{mg} / \mathrm{l}, 0.097 \mathrm{mg} / \mathrm{l}$, ) outline by NEQs of industrial and WHO. The study was focused on the Lead and acidic waste water of industry. Once soil/water become contaminated, the heavy metals remain in ecosystem. Since Pb is not biodegradable, it has capability to remain in environment (Pehlivan, 2009).

E. crassipes, $P$. stratiotes and $H$. umbellata were selected for experiment because they efficiently remove heavy metals and other pollutants with high reproduction rate, efficiency and tolerance of ecological factors.

The advantage of employing $\mathrm{NaOH}$ solution for adjusting $\mathrm{pH}$ of effluent to 7-7.5 is minimum sludge formation during neutralization reaction and product form is water-soluble $\mathrm{Na}_{2} \mathrm{SO}_{4}$ (sodium sulfate). Macchi et al.(1993) observe that in lead acid battery effluent sodium hydroxide solution precipitate (as hydroxides) resident ferric ions in the battery wastewater and scavenge the lead ions from the wastewater. Based on the minimal mass of moist sludge produced, acceptable residual lead concentration and lowest (among NaOH solutions) TDS of treated acidic waste water is suggested as an alternative agent to remediate the acidic wastewater from lead-acid battery manufacturing industry (Rao et al., 2010).

$\mathrm{Pb}$ uptake behavior of plants differ in plants (Fig $4 \mathrm{~A}, \mathrm{~B}, \mathrm{C}$ ). E. crassipes was the most successful candidate for removing $\mathrm{Pb}$ from the effluent and least accumulated by $H$. umbellata $(\mathrm{P}<0.05)$. The $P$. stratiotes showed fluctuation during the time period. At initial phase 0 9days the uptake was slow in E. crassipes than it was raised high on the $9^{\text {th }}$ day after wards it was rapid but steady. These results followed Leboudi et al., 2008 experiment in which the duration of slow initial phase of removal for $\mathrm{Pb}$ was during the period 2 to 6 days; thereafter, a much rapid rate of removal continued for remaining duration. Zhu et al. (1999) and Vesk et al. (1999) showed similar results of removing metals from industrial effluent treated with $E$. crassipes . Majeed et al., 2014 studies showed high removal of $\mathrm{Pb}\left(63.2 \mathrm{~g}^{-20 \mathrm{~L}}\right)$ than Water Lettuce from the effluent of Fuse Shop C-12, Pakistan Ordinance Factory. In P. stratiotes fluctuation of heavy metal in roots and shoots was observed from $9^{\text {th }}$ to $21^{\text {st }}$ day of experiment as reported by Vardanyan and Ingole, 2006, high metal concentrations in the roots of $P$. stratiotes. H. umbellata also showed fluctuation in absorption from day 0 to day 21.

The physical condition was recorded. E. crassipes accumulated most efficiently and steadily until the end of experiment, but necrosis and lack of chlorophyll was observed in most of plant leaves. Water deficiency was also recorded. No new plantlets were produced neither flowering occurred while reverse conditions were observed in the control condition; new plantlets, flowering and fresh green leaves were observed. Pistia stratiotes also showed lack of new plantlet production, necrosis and rolling of leaf tips. H. umbellata exhibited chlorosis, stunted growth and no production of new plantlets.

The conditions are as described by different scientists that higher concentrations of $\mathrm{Pb}$ significantly impact physiological activities of plant including water status and causing water deficit (Patra et al. 2004; Sharma and Dubey, 2005). Plants exposed to Pb ions showed a considerable decrease in the dry weight of different plant parts (Kosobrukhov et al. 2004; Sharma and Dubey, 2005), root elongation and new root development (Odjegba and Fasidi 2004, Sivalingam, 2016), and a decline in the total chlorophyll content, photosynthetic activity decline in the photosynthetic rate (Kambhampati et al. 2005, Tangahu et al, 2011). It has been shown that plants exposed to Pb ions showed a inhibited activities of Calvin cycle enzymes, as well as a deficiency of Carbon mono oxide due to stomatal closing (Sharma and Dubey, 2005 ). Mane et al. (2011) indicated that at lower concentrations $(5 \mathrm{mg} / \mathrm{L})$ of heavy metals, the plant growth was normal and removal efficiency was greater. Concentrations greater than $10 \mathrm{mg} / \mathrm{L}$, the plant started wilting and removal efficiency was reduced due to toxicity at higher metal concentrations.

Aquatic plants growth gets double and triple within 20 - 30 days and because of fast reproduction, decaying of old plant parts initiate (Vardanyan and Ingole. 2006). At the end of experiment, the plants were deteriorating and it was observed it is best to harvest the plants after 21 days. This evolution indicates that maximum period to allow the plants in the system is 21 days, Because plant reproduces rapidly 
and decays, the efficacy of the system is intimately linked to its careful management trough periodic harvesting of part of the biomass produced (Gupta et al., 2012). Decomposing of plants occur by consuming oxygen the process release the nutrients absorbed by the plants. (Cooke et al, 2005). Our results follow Fonkou et al., (2002) study who indicated that number of leaves per plant decreases, as a result of decay of the basal leaves that fall back into water, then releasing the substances that were absorbed after 15 days in all treatment ponds. According to the table 3 presenting the mean maximum and minimum contents of heavy metals in aquatic plants, higher mean content of $\mathrm{Pb}$ was found in E. crassipes (1412.9) than P. stratiotes and $H$. umbellata. E. crassipes is best accumulator of $\mathrm{Pb}$ from heavy metal contaminated effluents (Majeed et al., 2014 and Carvalho and Lenzi, 2000). Higher mean contents of Cd were found in H. umbellata (103.49) and least in $P$. stratiotes (28.35). The high values of bioconcentration factor of $\mathrm{Cd}(7173$, at $0.2 \mathrm{mg} / \mathrm{L})$ on day 9 of exposure was reported by Panyakhan et al., 2006 indicating $H$. umbellata better candidate for removal of $\mathrm{Cd}$ and $\mathrm{Zn}$ from contaminated water. Similarly, Cr and $\mathrm{Cu}$ was significantly $(\mathrm{P}>0.05 \%)$ absorbed by $P$. stratiotes $(119.41,28.47)$ and least absorbed by H. umbellata and E. crassipes $(91.00$, 19.068) respectively. Similar results were reported by Majeed et al., 2014, presenting $P$. stratiotes to be hyeraccumulator of $\mathrm{Cr}$ and $\mathrm{Cu}$.

\section{Conclusion and recommendations}

The content of heavy metals $\mathrm{Pb}, \mathrm{Cr}, \mathrm{Cu}$, and $\mathrm{Cd}$ in the phytomass of three aquatic plants growing in effluent coming from battery industry with the target of applying the findings to applications for control of heavy metal discharges in industrial effluents was studied. The main constituents of battery industry effluent include Lead $(\mathrm{Pb})$ and high acidity (2.1-2.3). The highest value of lead $(\mathrm{Pb})$ was observed in Eichhornia crassipes, $\mathrm{Cr}$ and $\mathrm{Cu}$ in P. stratiotes and $\mathrm{Cd}$ in H. umbellata. E. crassipes was found to be most successful in this experiment and recommended to be used to remediate battery industry effluent after adjusting the $\mathrm{pH}$ to $6-7$, as it absorbed high quantities of $\mathrm{Pb}$. The study reveals the potential and effectiveness of aquatic plant especially $E$. crassipes for remediation battery industry effluent. Removal after 21 to 25 day is highly suggested as with the passage of time plants will die and nutrients absorbed will be added to effluent.

Heavy metals uptake, by plants using phytoremediation technology, seems to be a successful way to remediate heavy metals-contaminated environment. Several factors must be considered in order to accomplish a high performance of remediation result. It can be recommended that

- Physicochemical properties of the battery industry effluent indicated emission of highly acidic water containing loads of heavy metal specifically Lead $(\mathrm{Pb})$.

- Industrial effluents should be treated before discharge from industry to reduce perilous impacts of acidity and heavy metals to surrounding biota environment.

- The most important factor is to select appropriate plant species which can be used to uptake the excessive contaminant. Phytoremediation potential of three aquatic macrophyte species (P. stratiotes, E. crassipes, and H. umbellata) cited in this study, Eichhornia crassipes was found most effective due to data achieved and available, research studies, fast growth, ability of biosorption and resistance to contaminants.

- Government should rigorously enforce environmental laws to avoid water pollution.

\section{References}

[1] Akar T and Tunali S (2006) Biosorption characteristics of Aspergillus flavus biomass for removal of $\mathrm{Pb}$ (II) and $\mathrm{Cu}$ (II) ions from an aqueous solution. Biosresource Technology. 97: 1780 - 1787. https://doi.org/10.1016/j.biortech.2005.09.009.

[2] Akinlua A, Asubiojo OI (2006) Physico-chemical and trace metal characterization of battery factory waste water. J. Appl. Sci. 6 (7):1456-1462. https://doi.org/10.3923/jas.2006.1456.1462.

[3] Akpor OB and Muchie M (2010) Remediation of heavy metals in drinking water and wastewater treatment systems: Processes and applications. International Journal of the Physical Sciences, 5(12):1807-1817.

[4] Ali K, Javid MA. Javid M (1996) Pollution and Industrial Waste. 6th National Congress Soil Sci; Lahore. pp. 122-131.

[5] Alka R. U. and B. D. Tripathi(2007) Principle and process of biofiltration of $\mathrm{CD}, \mathrm{Cr}, \mathrm{Co}, \mathrm{Ni}$ and $\mathrm{Pb}$ from tropical opencast colamine effluent. J. Water, Air, Soil, Poll. 180:213-223. https://doi.org/10.1007/s11270-006-9264-1.

[6] Alloway BJ (1990) In Heavy Metals in Soils (edt. Alloway B. J.), Blackie, Glasgow

[7] Anonymous, Massachusetts Institute of Technology 2009 Battery disposal. MIT. Department of Facilities.

[8] APHA (2001) Revisions to Standard Methods for the Examination of Water and Wastewater (Supplement). American Public Health Association, Washington DC.

[9] Baharudin, B and Shahrel M (2008) Lead and cadmium removal in synthetic wastewater using constructed wetland. Journal of Agricultural Technology 2012 Vol. 8(1): 1-11.

[10] Beal EO (1977) A manual of marsh and aquatic vascular plants of North Carolina with habitat data. Technical bulletin no. 247, North Carolina agricultural experiment station.

[11] Tangahu BV, Rozaimah S, Abdullah S, Basri H, Idris M, Anuar N, and Mukhlisin M (2011) A Review on Heavy Metals (As, Pb, and Hg) Uptake by Plants through Phytoremediation ; International Journal of Chemical Engineering , Article ID 939161, 31 pages. https://doi.org/10.1155/2011/939161.

[12] Buchmann I (2011) Batteries in a Portable World - A Handbook on Rechargeable Batteries for Non-Engineers, Third Edition, Cadex Electronics Inc., Richmond, Canada

[13] Cadmium Fact Sheet (2011) Environmental Protection Agency. Accessed on September 21. Available at: http: //www. epa. gov/ osw/ hazard/ waste$\mathrm{min} / \mathrm{minimize} /$ factshts /cadmium.pdf.

[14] Carvalho MDS and Lenzi E (2000) the aquatic macrophytes (Eichhornia crassipes) as a biological filter in treatment of lead contaminated effluents. Environ. Tech. 21:6, 615-622. https://doi.org/10.1080/09593330.2000.9618946.

[15] Cho-Ruk K, Kurukote J, Supprung P, and Vetayasuporn S (2006) Perennial plants in the phytoremediation of lead contaminated soils. Biotechnology, 5(1):1-4. https://doi.org/10.3923/biotech.2006.1.4.

[16] Chung IH, and Jeng SS (1974) Heavy metal pollution of Ta-Tu River. Bulletin of the Institute of Zoology, Academy of Sci. 13: 69-73.

[17] Barbieri de Souza C and Silva GR (2019) Chapter, "Phytoremediation of Effluents Contaminated with Heavy Metals by Floating Aquatic Macrophytes Species", Biotechnology and Bioengineering. Lusíada University Center (UNILUS), Santos, São Paulo, Brazil. https://doi.org/10.5772/intechopen.83645.

[18] Clesceri LS, Greenberg AE and Eaton AD, editors (1998) Standard method for the examination of water and wastewaster. 20th ed. American Public Health Association, Washington, DC.

[19] Cooke GD, Eugene BW, Spencer AP and Stanley AN (2005) Restoration and Management of Lakes and Reservoirs,. Third Edition.

[20] David TW, Than MM and Tun S ( 2003) Lead removal from industrial waters by water hyacinth. AU J. T., 6(4):187-192.

[21] Denike TJ and Geiger RW (1974) The utilization of Chara in water management. Hyacinth Control J., 12:18-20 
[22] Department of the Environment and Heritage (2005) Used lead acid batteries: Fact. Department of the Environment and Heritage, Australian Government.

[23] El-Gendy AS, Biswas N and Bewtra JK (2004) Growth of water hyacinth in municipal landfill leachate woth different pH., Environ. Technol., 25, 833-840. https://doi.org/10.1080/09593330.2004.9619375.

[24] Ensley B.(2000) Rational for use of phytoremediation. In: Raskin I,Ensley BD (eds) Phytoremediation of Toxic Metals: Using plants to clean up the environment. John Wiley \& Sons, New York, Inc. pp. 3-12.

[25] European Commission DG ENV. E3 (2000). Heavy Metals in Waste- Final Report. Project ENV.E.3/ETU/2000/0058, COWI A/S, Denmark.

[26] Fonkou T, Agendia P, Kengne I, Akoa A, and , Nya J (2002) Potentials of water lettuce (Pistia stratiotes) in domestic sewage treatment with macrophytic lagoon systems in Cameroon., In: Proc. of International Symposium on Environmental Pollution Control and Waste Management, Tunis, 709714.

[27] Ganjo DGA, and Khwakaram A (2010) Phytoremediation of waste water using some of aquatic macrophytes as biological purifier for irrigation purposed; removal efficiency and heavy metal Fe, Mn, Zn, and $\mathrm{Cu}$. World Academy of Science, Engineering and technology. 42:552-575

[28] Garty J (2001) Bio monitoring atmospheric heavy metals with lichens: theory and application. Critical Reviews in Plant Sciences, 20:309-371. https://doi.org/10.1080/20013591099254.

[29] Gosh M. and Singh SP (2005) A review on phytoremediation of heavy metals and utilization of its byproducts. App. Eco. And Environ. Res. 3(1): 1-18. http://www.ecology.kee.hu. ISSN 1589 1623. https://doi.org/10.15666/aeer/0301_001018.

[30] Govind P and Madhuri S (2014) Heavy Metals Causing Toxicity in Animals and Fishes. J. Animal, Veterinary and Fishery Sci. 2(2):17-23.

[31] Gupta P, Roy S, Mahindrakar AB (2012) Treatment of Water Using Water Hyacinth, Water Lettuce and Vetiver Grass - A Review. Resources and Environment: 2(5): 202-215. https://doi.org/10.5923/j.re.20120205.04.

[32] Gupta P, Roy S, Amit B. Mahindrakar ( 2012) Treatment of water using water hyacinth, water lettuce and vetiver grass-a review. Resour Environ 2(5):202-215. https://doi.org/10.5923/j.re.20120205.04.

[33] Health Effects of Hexavalent Chromium (2006) OSHA Factsheet. Occupational Safety and Health Administration. U.S. Department of Labor. July. Available at: http: //www. osha.gov/OshDoc/data_General_Facts/hexavalent_chromium.pdf.

[34] Hinchman RR, Negri MC and Gatliff EG (1995) Phytoremediation:using green plants to clean up contaminated soil, groundwater, and wastewater. Argonne National Laboratory and Applied Natural Sciences Inc.

[35] Hinchman, Applied Natural Sciences, Inc, (1995) http: //www. treemediation.com/ Technical/Phytoremediation 1998.pdf.

[36] John R, Ahmad P, Gadgi K and Sharma S. 2008. Effect of cadmium and lead on growth, biochemical parameters and uptake in Lemna polyrrhiza L. Plant Soil Environ. 54: 262-270. https://doi.org/10.17221/2787-PSE.

[37] Jurdziak M, Gać P, Martynowicz H, Poręba R (2015) Function of respiratory system evaluated using selected spirometry parameters in persons occupationally exposed to lead without evident health problems. Environ Toxicol Pharmacol.;39:1034-1040. https://doi.org/10.1016/j.etap.2015.03.009.

[38] Kambhampati MS, Begonia GB, Begonia MFT and Bufford Y (2005) Morphological and physiological responses of morning glory (Ipomoea lacunose L.) grown in a lead- and chelate-amended soil. International Journal of Environmental Research and Public Health. 2: $299-303$. https://doi.org/10.3390/ijerph2005020014.

[39] Khilji S and Bareen F (2008) Rhizofiltration of heavy metal from the tannery sludge by the anchored hydophyte, Hydrocotyle umbellate L., Afric. J. Biotech. 7: 3711-3717

[40] Kosobrukhov A, Knyazeva I and Mudrik V (2004) Plantago major plants responses to increase content of lead in soil: growth and photosynthesis. Plant Growth Regulation, 42:145-151. https://doi.org/10.1023/B:GROW.0000017490.59607.6b.

[41] Kumar NJI, Soni H, Kumar RN and Bhatt (2008) Macrophytes in phytoremediation of heavy metal contaminated water and sediments in Pariyej Community Reserve, Gujarat, India. Turkish Journal of Fisheries and Aquatic Sciences. 8: 193-200.

[42] Kutty SRM, Ngatenah SNI, Isa MH and Malakahmad A (2009) Nutrients removal from municipal wastewater treatment plant effluent using Eichhorinacrassipes. World Acad. Sci. Engineering and Technol., 60: 826-831.

[43] Lasat MM ( 2002) Phytoextraction of toxic metals: a review of biological mechanism. Journal of Environmental Quality 31: 109-120. https://doi.org/10.2134/jeq2002.1090.

[44] Lead: When are you most at risk?”. Accessed on August 30, 2011. Available at: http://www.hse.gov.uk/lead/mostatrisk.htm.

[45] Leboudi AE EL, Abd-Elmoniem M, M.Soliman E and El-Sayed O (2008) Removal of Some Heavy Metals from Treated Waste Water by Aquatic Plants. The 3rd International Conference on Water Resources and Arid Environments and the 1st Arab Water Forum.

[46] Liao SW and Chang WL (2004) Heavy Metal Phytoremediation by Water Hyacinth at Constructed Wetlands in Taiwan. J. Aquat. Plant Manage., 42: 60-68.

[47] Licina V, Antic-Mladenovic S, Kresovic M (2007) the accumulation of heavy metals in plants (Lactuca sativa L., Fragaria vesca L.) after the amelioration of coalmine tailing soils with different organic-mineral amendments. Archives of Agronomy and Soil Science 53, 39-48. https://doi.org/10.1080/03650340601100255.

[48] Lokhande RS, Singare PU, and Pimple DS (2011) Toxicity study of heavy metals pollutions in waste water effluent samples collected from Taloja Industry Estate of Mumbai, India. Res and Environ. 1: 13-19.

[49] Lu Q, Zhenli L He, Donald AG, Peter JS and Xiaoe Y (2011) Uptake and distribution of metals by Water Lettuce (Pistia stratiotes L.). Environmental science and pollution research international. 18(6): 978-986. https://doi.org/10.1007/s11356-011-0453-0.

[50] Lu, X., Kruatrachue M, Pokethitiyook P and Homyok K (2004) Removal of cadmium and zinc by water hyacinth Eichhornia crassipes. Science Asia. 30: 93-103. https://doi.org/10.2306/scienceasia1513-1874.2004.30.093.

[51] Macchi G, Pagang M, Santori M and Tiravanti G (1993) Battery industrial wastewater: Pb removal and produced sludge. Water Res., 27: 1511-1518. https://doi.org/10.1016/0043-1354(93)90095-Y.

[52] Madhura K, Chotu J and Fulekar MH (2006) Rhizofiltration of heavy metals from coal ash leachate. Asian Journal of Water, Environment and Pollution. 3(1): 91-94.

[53] Maine MA, Sune NL and Lagger SC (2004) Chromium bioaccumulation: Comparison of the capacity of two floating aquatic macrophytes. Water Research Oxford 38:1494-1501. https://doi.org/10.1016/j.watres.2003.12.025.

[54] Mane AV, Saratale GD, Karadge BA and Samant JS ( 2011). Studies on the effects of salinity on growth, polyphenol content and photosynthetic response in Vetiveria zizanioides (L.) Nash., Emir. J. Food Agric., 23(1), 59-70. https://doi.org/10.9755/ejfa.v23i1.5313.

[55] Mishra VK, Upadhyaya AR, Pandey SK, and Tripathi BD (2008) Bioresource Technol. 99: 930 https://doi.org/10.1016/j.biortech.2007.03.010.

[56] Mishra VK, Upadhyaya AR, Pandey SK, and Tripathi BD (2008) Concentrations of heavy metals and aquatic macrophytes of Govind Ballabh Pant Sagar an anthropogenic lake affected by coal mining effluent. Environmental Monitoring and Assessment 141:49-58. https://doi.org/10.1007/s10661007-9877-x.

[57] Mo S, DS and Robinson Chol JW (1989) Uptake of mercury from aqueous solution by Duckweed: the effect of pH, copper, and humic acid. Environ. Health 24: 135-146. https://doi.org/10.1080/10934528909375470.

[58] Mokhtar H, Morad N, Ahmad F (2011) Hyperaccumulation of copper by two species of aquatic plants. Intern. Conf. Environ. Sci. Eng. IPCBEE 8. IACSIT Press, Singapore.

[59] Mubin S, Gul MIA, Khokhar and Ashraf M. 2002. Journal of Drainage and Water Management. 6 (2): 55-68.

[60] Mukherjee, S and Mondal GC (1995). Removal of lead by water hyancinth. Indian. J. Chem. Technol., 2:5962.

[61] National environmental quality standards (NEQs) (2000) the gazette of Pakistan, Notification SRO No. 549 (I)/ 2000 , Pakistan urban and environmental affair division, Islamabad.

[62] Odjegba VJ and Fasidi IO (2004) Accumulation of trace elements by Pistia stratiotes: implications for phytoremediation. Ecotoxicology, 13, 637646. https://doi.org/10.1007/s10646-003-4424-1. 
[63] Orisakwe OE, Asomugha R, Afonne OJ, Anisi CN, Obi E and Dioka CE (2004) Impact of effluents from a car battery manufacturing plant in Nigeria on water, soil, and food qualities. Arch. Eniron. Health 59(1):31-6. https://doi.org/10.3200/AEOH.59.1.31-36.

[64] Sharma P and Dubey RS (2005) Lead toxicity in plants, Brazilian Journal of Plant Physiology 17(1) : $35-52$ March 2005. https://doi.org/10.1590/S1677-04202005000100004.

[65] Panyakhan S, Kruatrachue M, Pokethitiyook P, Soonthornsarathoona V and Upathamc S (2006) Toxicity and Accumulation of Cadmium and Zinc in Hydrocotyle umbellata.

[66] Patra M, Bhowmik N, Bandopadhyay B and Sharma A (2004) Comparison of mercury, lead and arsenic with respect to genotoxic effects on plant systems and the development of genetic tolerance. Environmental and Experimental Botany. 52: 199-223. https://doi.org/10.1016/j.envexpbot.2004.02.009.

[67] Pehlivan E, O“ zkan AM, Dinc S and Parlayici S (2009) Adsorption of Cu2+ and Pb2+ ion on dolomite powder. J. of Hazardous Materials. 167 (13):1044-1049. https://doi.org/10.1016/j.jhazmat.2009.01.096.

[68] Pieterse AH, DeLange L and Verhagen L (1981) A study on certain aspects of seed germination and growth of Pistia stratiotes L. Acta Botanica Neerlandica. 30:47-57. https://doi.org/10.1111/j.1438-8677.1981.tb00386.x.

[69] Pooja M. and J. Kaushal (2018) Role of Phytoremediation in Reducing Cadmium Toxicity in Soil and water. Journal of Toxicology, 16 pages. https://doi.org/10.1155/2018/4864365.

[70] Qin L, Zhenle LH, Donald AG, Stoffella PJ and Xiaoe Y (2011) Uptake and distribution of metals by water lettuce (Pistia stratiotes L.) Environ. Sci. and Pollut. Res. 18(6): 978-986. https://doi.org/10.1007/s11356-011-0453-0.

[71] Rahangdale RV, Kore SV and Kore VS (2012) Waste management in lead-acid battery industry: A case study. World Journal of Applied Economics. 1(1): 7-12.

[72] Ramus K and Hawkins $\mathrm{P}(1992)$ Lead/Acid battery recycling and the new is a smelt process.

[73] Rashed MN. 2003. Fruit stones as adsorbents for the removal of lead ion from pollutedwater. http://www.eeaa.gov.eg/English/main/Env2003/Day2/Water/rashed.uniaswan

[74] Raskin I, Smith RD and Salt DE (1997) Phytoremediation of metals: using plants to remove pollutants from the environment. Current Opinion in Biotechnology. 8: 221-226. https://doi.org/10.1016/S0958-1669(97)80106-1.

[75] Rathor G, Neelam C and Tapan A (2014) Effect of variation in Nickel concentration on Growth of Maize plant: A comparative over view for Pot and Hoagland culture. Res. J. Chem. Sci. Vol. 4(10), 30-32, October

[76] Reddy KR and DeBusk WF (1987) Nutrient storage capabilities of aquatic and wetland plants. In: K. R, Reddy, W.H. Smith, “Aquatic plants for water treatment and resource recovery", Orlando, Florida: Magnolia Publishing, pp. 337-357.

[77] Roy A, Queirolo E, Peregalli F, Mañay N, Martínez G, Kordas K. (2015) Association of blood lead levels with urinary F2-8 $\alpha$ isoprostane and 8hydroxy-2-deoxy-guanosine concentrations in first-grade Uruguayan children. Environ Res. 140: 127-135. https://doi.org/10.1016/j.envres.2015.03.001.

[78] Saha P, Shinde O, Sarkar S (2015) Phytoremediation potential of Duckweed (Lemna minor L.) on steel wastewater. International Journal of Phytoremediation 17:589-596, https://doi.org/10.1080/15226514.2014.950410.

[79] Sanchez-Galvan G, Monroy O, Gomez J, and Olguin EJ (2008) Assessment of the hyper accumulating lead capacity of Salvinia minima using bioadsorption and intracellular accumulation factors. Water, Air, and Soil Pollution 194:77-90. https://doi.org/10.1007/s11270-008-9700-5.

[80] Sarnowski P. and Jezierska B (2007) A new coefficient for evaluation of condition of fish. Electronic Journal of Ichthyology, 2:69-76.

[81] Shah SL, Altindac A (2005) Effects of Heavy Metal Accumulation on the 96-h LC50 Values in Tench Tinca tinca: Turkish Journal Veterinary Animal Science. 29:139-144.

[82] Sharma P and Dubey RS (2005) Lead toxicity in plants. Braz. J. Plant Physiol. 17 (1):35-52. https://doi.org/10.1590/S1677-04202005000100004.

[83] Singh OV, Labana S, Pandey G, Budhiraja R, Jain RK (2003) Phytoremediation: An overview of metallic ion decontamination from soil. Appl. Microbiol. Biotechnol., 61: 405-412. https://doi.org/10.1007/s00253-003-1244-4.

[84] Sivalingam, M. Thirumarimurgan, Alagarasan V, Balasanthar M, Manogaran, G (2016) Phytoremediation of Bacopa Monnieri in Lead-Contaminated Battery Effluent. IJSRD - International Journal for Scientific Research \& Development Vol. 4( 02) ISSN (online): 2321 -0613

[85] Soltan ME and Rashed MN (2003). Laboratory study on the survival of water hyacinth under several conditions of heavy metal concentrations. Adv. Environ. Res. 7:321-334. https://doi.org/10.1016/S1093-0191(02)00002-3.

[86] Sudhakar MR and Rajo GC (2010) Comparison of alkaline treatment of lead contaminated wastewater using lime and sodium hydroxide. J. Water Resource and Protection. 2:282-290. Published Online March 2010 (http ://www .scirp. org/ journal /jwarp) https://doi.org/10.4236/jwarp.2010.23032.

[87] Tangahu BV, Abdullah SRS, Basri H, Idris M, Anuar N and Mukhlisin M ( 2011) A review on heavy metals (As, Pb, and Hg) uptake by plants through phytoremediation. Int. J. Chem. Eng. 2011:1-31. https://doi.org/10.1155/2011/939161.

[88] Terry N, Banuelos G (2000) Phytoremediation of Contaminated Soiland Water. Lewis Publishers, New York

[89] United State Environmental Protection Agency (EPA) (2005) Groundwater current standards 24/12/2005. National Primary Drinking Water Standards $1-12$

[90] Upadhyay AR and Tripathi BD (2007) Water Air Soil Pollut. 180: 213. https://doi.org/10.1007/s11270-006-9264-1.

[91] Upadhyay AR, Mishra VK, Pandey SK and Tripathi BD (2007) Biofiltration of secondary treated municipal wastewater in tropical city. Ecol. Eng. 30: 9-15. https://doi.org/10.1016/j.ecoleng.2006.09.004.

[92] Upadhyay AR, Mishra VK, Pandey SK and Tripathi BD (2007) Ecol. Eng. 30: 9. https://doi.org/10.1016/j.ecoleng.2006.09.004

[93] Vardanyan, L.G., and B.S. Ingole (2006) Studies on heavy metal accumulation in aquatic macrophytes from Sevan (Armenia) and Carambolim (India) Lake systems. Environ. Int. 32:208-218. https://doi.org/10.1016/j.envint.2005.08.013.

[94] Vesely T, Tlustos P and Szakova J (2011) the use of water lettuce (Pistia stratiotes L.) for rhizofiltration of a highly polluted solution by cadmium and lead. Int. J. Phytoremediation; 13(9):859-72. https://doi.org/10.1080/15226514.2011.560214.

[95] Wallace, H (2000) Principles and Methods of Toxicology. 4th Edition. Taylor and Fransic: Boston, MN. ISBN 1560328142.

[96] Weiliao S and Chang WL (2004) Heavy Metal Phytoremediation by Water Hyacinth at Constructed Wetlands in Taiwan. J. Aquat. Plant Manage. 42: $60-68$

[97] Wolverton BC and McDonald RC (1975a) Water hyacinths and alligator weeds for removal of silver, cobalt, and strontium from polluted waters. NASA Tech.Memo., (TM-X-72727).

[98] Wolverton BC (1975) Water hyacinths for removal of cadmium and nickel from polluted waters. NASA Tech.Memo., (TM-X-72721):11 p. Issued also in Sci.Tech.Aerospace Rep., 13(7):795-6

[99] Wolverton BC (1975a) Water hyacinth for removal of phenols from polluted waters. NASA Tech. Memo., (TM-X-72722): 18 p. Issued also in Sci.Tech.Aerospace Rep, 13(7):795

[100] World Health Organization (WHO) (1993) Guidelines for drinking water quality. Vol:1: Recommendation, 2nd edition. Geneva, Switzerland.

[101] Yongpisanphop J, Kruatrachue M and Pokethitivook P (2005) Toxicity and accumulation of lead and chromium in Hydrocotyle umbellata. J. Environ. Biol. 26(1):79-89.

[102] Yurukova L and Kochev K (1994) Heavy metal concentra $\neg$ tions in freshwater macrophytes from the Aldomirovsko swamp in the Sofia District, Bulgaria. Bulletin of Environ $\neg$ mental Contamination and Toxicology. 52(4): 627-632. https://doi.org/10.1007/BF00194153.

[103] Zhan XM and Zhao Z (2003) Mechanism of lead adsorption from aqueous solutions using an adsorbent synthesized from natural condensed tannin. Water Research. 37: 3905-3912. https://doi.org/10.1016/S0043-1354(03)00312-9.

[104] Zhu YL, Zayed AM, Qian JH, De Souza M and Terry N (1999) Phytoaccumulation of trace elements by wetland plants: II. Water hyacinth. J Environ Qual. 28 (1): 339-344. https://doi.org/10.2134/jeq1999.00472425002800010042x. 